\title{
The impact of the patient's condition, diagnostic procedures and treatment on the survival of carcinoma of unknown primary site patients
}

This article was published in the following Dove Press journal: Cancer Management and Research

\author{
Karolina Dorobisz' \\ Iwona Wlodarska-Polinska ${ }^{2}$ \\ Katarzyna Pazdro-Zastawny' \\ Tomasz Rutkowski ${ }^{3}$ \\ Piotr Palka ${ }^{3}$ \\ Tomasz Dworzecki \\ Tomasz Zatonski' \\ 'Department of Otolaryngology, Head \\ and Neck Surgery, Wroclaw Medical \\ University, Wrocław, Poland; \\ ${ }^{2}$ Department of Radiotherapy, \\ Oncotherapy International Center, \\ Walbrzych, Poland; ${ }^{3}$ Department of \\ Radiation and Clinical Oncology, Maria \\ Skłodowska-Curie Memorial Cancer \\ Center and Institute of Oncology, \\ Gliwice, Poland
}

Introduction: Carcinoma of unknown primary site (CUP) refers to $1-5 \%$ of all head and neck neoplasms. Very often, the primary site remains difficult to determine. Squamous cell carcinoma is the most frequent histopathological type diagnosed in the head and neck region. According to statistics, a primary site is usually located in the oropharynx.

Study objective: The study presents diagnostic difficulties and the methods of diagnosing and the therapy of CUP and primary sites in patients treated in the region of Lower Silesia and Silesia. The aim of the study was to show a retrospective analysis of 233 CUP patients to assess how clinical features, diagnosis and treatment affect the survival of patients.

Material and methods: The diagnostics of patients included panendoscopy with specimen collection (nasoendoscopy, laryngoscopy, esophagoscopy, brochoscopy), computed tomography examination of the neck, chest, abdomen and pelvis minor, as well as positron emission tomography examination. Tonsilletomy was performed in 37 patients. Neck dissection was carried out in 109 subjects and 165 patients were treated bt radiotherapy, and 135 by chemotherapy.

Conclusions: Tonsillectomy is required in CUP patients with the negative results of biopsy and imaging tests. It gives a possibility of detecting the primary site and improves the results of treatment and survival of CUP patients.Combination therapy, including surgical treatment and chemoradiotherapy, gives the best therapeutic results in CUP patients. The general condition of patient and younger age have an impact on prognosis and survival.

Keywords: carcinoma of unknown primary site, squamous cell carcinoma, head and neck surgery, head and neck cancer

\section{Introduction}

Carcinoma of the unknown primary site (CUP) is a neoplasm in which there are metastases to the lymph nodes and distant metastases but the detection of a primary focus is not feasible. ${ }^{1}$ CUP involves $2-5 \%$ of head and neck neoplasms. ${ }^{1}$ It is more often found in men with the mean survival time of 36 months starting from the appearance of the lesion in the neck. ${ }^{2}$ Squamous cell carcinoma (SCC) is the most common histopathological type found in metastatic lymph nodes; it is reported in over $75 \%$ of cases. ${ }^{2}$ Other histopathological CUP types detected less frequently are adenocarcinoma, undifferentiated carcinoma and melanoma. ${ }^{2}$

There are many hypotheses how CUP arises including the concept of the greater affinity of the neoplasm for lymph node cells, with the faster tumor growth inside the node than at the primary site. ${ }^{3}$ Another possible CUP etiology is related to the
Correspondence: Karolina Dorobisz Department of Otolaryngology, Head and Neck Surgery, Wroclaw Medical University, Borowska 213, Wrocław, Poland

Tel +48 50 I20 7964

Email dorobiszkarolina@gmail.com 
immunological regression of the primary site. ${ }^{3}$ The last hypothesis which is at least probable is the lack of the primary site with the transformation inside the lymph nodes as the only place of tumor. However, this seems to be an erroneous statement because the primary site is usually revealed with a delay.

According to the literature, tobacco smoking and alcohol abuse, as well as Human Papilloma Virus (HPV) infection, especially in highly developed countries, are the main risk factors. ${ }^{4}$ According to the literature, p16 negative and $\mathrm{p} 53$ positive patients have the worst prognosis, while p16 positive individuals have the greatest possibilities of survival.,

Diagnostics of CUP is based on a detailed ENT examination and panendoscopy with the collection of specimens from the altered airway mucosa. Tonsillectomy, computed tomography (CT), magnetic resonance imaging (MRI) and positron emission tomography (PET) are recommended. ${ }^{6}$ The primary site is most often found in the oral part of the throat, ie, in the palatine tonsils and the root of the tongue. $^{7-9}$ According to the literature, CUP patients usually have positive HPV test results. ${ }^{7-9}$ Despite of very thorough diagnostic procedures, a primary site is not found in $40 \%$ of patients. ${ }^{10,11}$ The treatment of CUP requires cooperation of doctors of many medical specialties. The method of treatment depends on the histopathological type of the tumor located in the affected lymph nodes - their amount, location and the presence of distant metastases. The treatment involves the surgical removal of the neck lymph nodes, radiotherapy and/or chemotherapy. Radiotherapy usually covers a large area of the head and neck. Despite of the progress in numerous fields of medicine, such as histology, immunology, immunohistochemistry and imaging diagnostics, it is still difficult to determine the location of the primary site. The appropriate oncological treatment can be implemented only after finding the primary site which gives incomparably better results. The worldwide incidence of CUP is decreasing, due to an improvement of diagnostic methods and faster diagnosis of the primary site. However, poor prognosis in this group of patients requires further studies on this subject.

\section{Study objective}

The study presents diagnostic difficulties and the methods of diagnosing and therapy of CUP and primary sites in patients treated in the region of Lower Silesia and Silesia. The aim of the study was to show a retrospective analysis of CUP patients to assess how clinical features and treatment affect the survival of patients.

\section{Materials and methods}

The study included 233 patients with a metastatic lymph node but without the presence of the primary site. In some of the patients, the primary site was found with a delay. The diagnostics of patients included panendoscopy with specimen collection (nasoendoscopy, laryngoscopy, esophagoscopy, brochoscopy), CT examination of neck, chest, abdomen and pelvis minor, as well as PET examination. Tonsilletomy was performed in 37 patients. Neck dissection was carried out in 109 subjects and 165 patients were treated by radiotherapy, and 135 by chemotherapy. Neck dissection was performed unilaterally or bilaterally based on the result of the CT of the neck. During radiotherapy, the patients received a standard dose of $2 \mathrm{~Gy}, 5$ times a week. Radiation dose was 66-72 Gy. The irradiated area included the nasopharynx, the base of the tongue, tonsillar fossa, hypopharynx and bilaterally the neck to the larynx. Cisplatin and 5-fluorouracil were applied in chemotherapy. Cisplatin was used during chemoradiotherapy. In the first half-year, the patients were controlled every month, in the following year every 3 months and later every 6 months until the end of the fifth year from the moment of diagnosis.

The analysis was based on gender, age (division into age groups $-<50,50-60,60-70,>70$ ), the condition of the patient according to the ECOG scale, disease severity according to the TNM scale by the American Joint Committee for Cancer Staging, a group of the affected lymph nodes in the neck (group I, II, III < IV, V, VI), diagnostic procedures implemented, histopathological type of the tumour found in the metastatic lymph node, the type of treatment, the location of the primary site if known and the survival of patients from the moment of diagnosis. Exclusion criteria included an incomplete medical history or therapy, the loss of the patient for the follow-up and the medical history of oncological treatment for another cancer in the past. Basic statistics of the patients' characteristics are presented in Table 1 in the form of numbers (n) and percentages (\%).

The patients were divided into three subgroups based on the time of survival after treatment: survival $<12$ months, survival from 12 to 24 months, survival $>24$ months. Numbers (n) and percentages (\%) of the patients in individual subgroups that differed in terms of survival and of the level of the feature analyzed are included in the 
Table I Characteristics of the subjects

\begin{tabular}{|c|c|}
\hline Variable & Total $\mathbf{N}=233$ \\
\hline \multicolumn{2}{|l|}{ Gender: } \\
\hline Female & $56(24.0 \%)$ \\
\hline Male & 177 (76.0\%) \\
\hline \multicolumn{2}{|l|}{ Age (years): } \\
\hline$<50$ & 31 (13.3\%) \\
\hline $50-60$ & $82(35.2 \%)$ \\
\hline $60-70$ & $92(39.5 \%)$ \\
\hline$>70$ & $18(12.0 \%)$ \\
\hline \multicolumn{2}{|l|}{ Degree of spread to regional } \\
\hline $\mathrm{NI}$ & $33(14.2 \%)$ \\
\hline N2 & $100(42.9 \%)$ \\
\hline N3 & $100(42.9 \%)$ \\
\hline Panendoscopy revealed primary tumor & $n=105$ \\
\hline Yes & $36(34.3 \%)$ \\
\hline No & 69 (65.7\%) \\
\hline PET - revealed primary tumor & $n=70$ \\
\hline Yes & $31(44.3 \%)$ \\
\hline No & 39 (55.7\%) \\
\hline \multicolumn{2}{|l|}{ Cervical lymph node groups: } \\
\hline 1 & $9(3.9 \%)$ \\
\hline$\|$ & $205(88.0 \%)$ \\
\hline III & $144(61.8 \%)$ \\
\hline IV & $59(25.3 \%)$ \\
\hline$\vee$ & $31(13.3 \%)$ \\
\hline VI & $2(0.9 \%)$ \\
\hline Tonsillectomy & $37(15.9 \%)$ \\
\hline \multicolumn{2}{|l|}{ Pathologic type: } \\
\hline I - Squamous cell carcinoma & $202(86.7 \%)$ \\
\hline 2 - Adenocarcinoma & $8(3.4 \%)$ \\
\hline 3 - Melanoma & $8(3.4 \%)$ \\
\hline 4 - Lymphoma & I $(0.5 \%)$ \\
\hline 5 - Other & $14(6.0 \%)$ \\
\hline Surgery & $109(46.8 \%)$ \\
\hline Radiotherapy & $165(71.4 \%)$ \\
\hline Chemotherapy & I 35 (57.9\%) \\
\hline \multicolumn{2}{|l|}{ ECOG performance status: } \\
\hline 0 & $103(44.2 \%)$ \\
\hline I & $96(41.2 \%)$ \\
\hline 2 & 26 (II.2\%) \\
\hline 3 & $7(3.0 \%)$ \\
\hline 4 & $\mathrm{I}(0.4 \%)$ \\
\hline \multicolumn{2}{|l|}{ Treatment: } \\
\hline Radical & 135 (57.9\%) \\
\hline Palliative & $98(42.1 \%)$ \\
\hline
\end{tabular}

cross tables and their relationship was verified using the chi-square test of independence.

In addition, ORs have been calculated to determine the ratio of the survival rate of 12 (or 24) months in a given group to the survival rate in another (reference) group. For this purpose, four-field cross tables $(2 \times 2)$ were created for each analyzed feature (risk factor) where the survival was analyzed on two levels: survival of 12 months and above 24 months. Qualitative features (risk factors) with more than two levels were reduced to two levels (eg, age up to 70 years vs over 70 years, proximal metastases to the lymph nodes N1 or N2 vs distant metastases N3). The tables also include $95 \%$ confidence intervals for OR.

Given a very strong influence of the severity of the disease, expressed by the extent of spread to the lymph nodes, on a 12- and 24-month survival, in the analysis of the impact of other risk factors (age, type of treatment, surgical treatment, radiotherapy, chemotherapy) the values of odds ratio were adjusted by $\mathrm{N}$ parameter $\left(\mathrm{OR}_{\mathrm{adj}}\right)$. The extent of metastases to the lymph nodes was treated as a confounder and stratification was applied for the calculation of the adjusted $\mathrm{OR}_{\mathrm{adj}}$.

$P<0.05$ was considered statistically significant. The statistical analysis was carried out using the Statistica 12 program (StatSoft, Inc., Tulsa, OK, USA).

\section{Results}

In the group of 233 patients, $44.6 \%$ did not survive 12 months, $19.8 \%$ died before 2 years and $35.6 \%$ survived more than 2 years (Figure 1).

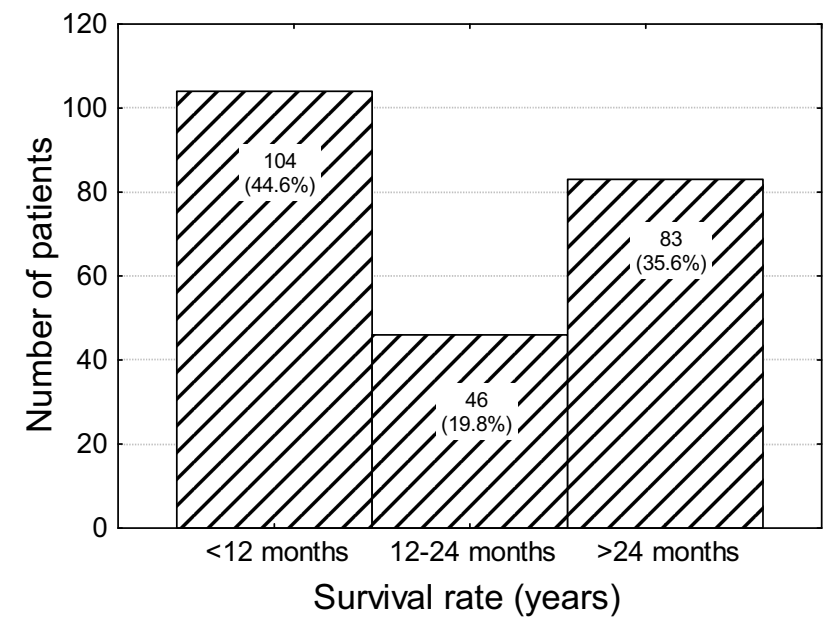

Figure I Number (percentage) of patients in subgroups that differ in terms of survival. 


\section{Tumour location and survival}

A statistically significant correlation was reported between the location of the primary site and survival $(P<0.01)$. The survival rate of 12 months in patients with the primary site in the oropharyngx, nasopharyngx or larynx is eight times higher $(\mathrm{OR}=8.65)$ than in the subjects with the tumor in the throat, lungs or salivary glands. The survival rate of 24 months is 6 times higher $(\mathrm{OR}=6.77)$ in this group of patients. This data is illustrated in Tables 2 and 3.

\section{$\mathrm{N}$ type and survival}

A statistically significant relationship was found between the type of lymph node metastases and survival $(P<0.001)$. It has been shown that patients with $\mathrm{N} 1$ or $\mathrm{N} 2$ type have significantly better survival rates of over 24 months (Table 4).

The survival rate of 12 months in patients with metastases to the lymph nodes type $\mathrm{N} 1$ or $\mathrm{N} 2$ is seven times higher than in $\mathrm{N} 3$ patients $(\mathrm{OR}=7.42)$ and the survival rate of 2 years almost four times higher $(\mathrm{OR}=4.81)$. This data is illustrated in Table 5.

\section{Age and survival}

A statistically significant correlation was observed between age and survival $(P<0.05)$. The survival rate of over 12 months in patients over 70 years of age was reported in $32.2 \%$, while $67.9 \%$ did not survive 12 months. The prognosis in patients under 50 is better, the

Table 2 Number (percentage) of patients in groups differing in the location of a primary site and survival, the result of the test of independence

\begin{tabular}{|c|c|c|c|c|}
\hline \multirow[t]{2}{*}{ Primary site of cancer } & \multicolumn{3}{|c|}{ Survival rate (months) } & \multirow[t]{2}{*}{$P$-value } \\
\hline & $<12$ & $12-24$ & $>24$ & \\
\hline Oropharynx $(n=4 I)$ & 10 (24.4\%) & $10(24.4 \%)$ & $21(51.2 \%)$ & 0.002 \\
\hline Nasopharynx $(n=18)$ & $2(11.1 \%)$ & $3(16.7 \%)$ & $13(72.2 \%)$ & \\
\hline Laryngophanyx $(n=15)$ & $10(66.7 \%)$ & $3(20.0 \%)$ & $2(13.3 \%)$ & \\
\hline Larynx $(n=12)$ & $2(16.7 \%)$ & $4(33.3 \%)$ & $6(50.0 \%)$ & \\
\hline Lung $(n=7)$ & 5 (7I.4\%) & $0(0.0 \%)$ & $2(28.6 \%)$ & \\
\hline Skin $(n=5)$ & $2(40.0 \%)$ & $2(40.0 \%)$ & I (20.0\%) & \\
\hline Salivary gland $(n=3)$ & $2(66.6 \%)$ & I (33.3\%) & $0(0.0 \%)$ & \\
\hline Lip $(n=2)$ & I (50.0\%) & I (50.0\%) & $0(0.0 \%)$ & \\
\hline Oral cavity $(n=1)$ & $0(0.0 \%)$ & $0(0.0 \%)$ & I (I00\%) & \\
\hline Lymphoma $(n=1)$ & $0(0.0 \%)$ & I (I00\%) & $0(0.0 \%)$ & \\
\hline Esophagus $(n=I)$ & I (100\%) & $0(0.0 \%)$ & $0(0.0 \%)$ & \\
\hline Cervix utemi $(n=I)$ & $0(0.0 \%)$ & I (100\%) & $0(0.0 \%)$ & \\
\hline Prostate $(n=1)$ & $0(0.0 \%)$ & I (I00\%) & $0(0.0 \%)$ & \\
\hline Thyroid $(n=1)$ & $\mathrm{I}(100 \%)$ & $0(0.0 \%)$ & $0(0.0 \%)$ & \\
\hline Unknown $(n=124)$ & 68 (54.8\%) & 19 (I5.3\%) & 37 (29.7\%) & \\
\hline
\end{tabular}

Note: Bold values represent statistically significant.

Table 3 Number (percentage) of patients in groups differing in the location of a primary site and a 12-month survival or 24-month survival, the result of the test of independence and odds ratio ( $95 \%$ confidence interval)

\begin{tabular}{|c|c|c|c|c|}
\hline \multirow[t]{2}{*}{ Primary site of cancer } & \multicolumn{2}{|c|}{ I 2-month survival } & \multirow[t]{2}{*}{$P$-value } & \multirow[t]{2}{*}{ OR $(95 \% \mathrm{Cl})$} \\
\hline & $\begin{array}{l}\text { Yes } \\
N=65\end{array}$ & $\begin{array}{l}\text { No } \\
N=31\end{array}$ & & \\
\hline $\begin{array}{l}\text { Oropharynx, nasopharynx or larynx } \\
\text { Laryngophanyx, lung or salivary gland }\end{array}$ & $\begin{array}{l}57(87.7 \%) \\
8(12.3 \%)\end{array}$ & $\begin{array}{l}14(45.2 \%) \\
17(54.8 \%)\end{array}$ & $<0.001$ & $\begin{array}{l}8.65 \text { (3.II- 24.I) } \\
\mathrm{I} .00 \text { (ref.) }\end{array}$ \\
\hline \multirow[t]{2}{*}{ Primary site of cancer } & \multicolumn{2}{|c|}{ 24-month survival } & $P$-value & OR $(95 \% \mathrm{Cl})$ \\
\hline & $\begin{array}{l}\text { Yes } \\
N=44\end{array}$ & $\begin{array}{l}\text { No } \\
N=52\end{array}$ & & \\
\hline $\begin{array}{l}\text { Oropharynx, nasopharynx or larynx } \\
\text { Laryngophanyx, lung or salivary gland }\end{array}$ & $\begin{array}{l}40(90.9 \%) \\
4(9.1 \%)\end{array}$ & $\begin{array}{l}31(59.6 \%) \\
21(40.4 \%)\end{array}$ & $<0.001$ & $\begin{array}{l}6.77(2.11-21.8) \\
1.00 \text { (ref.) }\end{array}$ \\
\hline
\end{tabular}


Table 4 Number (percentage) of patients in groups differing in the extent of spread to the lymph nodes $(\mathrm{N})$ and survival, the result of the test of independence

\begin{tabular}{|l|l|l|l|l|}
\hline \multirow{2}{*}{$\begin{array}{l}\text { Survival rate } \\
\text { (months) }\end{array}$} & \multicolumn{2}{|l|}{ Degree of spread to regional } & \multirow{2}{*}{-value } \\
\cline { 2 - 4 } & $\begin{array}{l}\text { NI } \\
\text { N=33 }\end{array}$ & $\begin{array}{l}\text { N2 } \\
\text { N=100 }\end{array}$ & $\begin{array}{l}\text { N3 } \\
\text { N=100 }\end{array}$ & \\
\hline $\begin{array}{l}\text { <12 months } \\
\begin{array}{l}\text { From 12 to } 24 \\
\text { months }\end{array}\end{array}$ & $10(30.3 \%)$ & $23(23.0 \%)$ & $71(71.0 \%)$ & $<0.00$ I \\
$\begin{array}{l}\text { More than } 24 \\
\text { months }\end{array}$ & $14(42.4 \%)$ & $25(25.0 \%)$ & $12(12.0 \%)$ & \\
\hline
\end{tabular}

Note: Bold value represents statistically significant.

period over 24 months since the moment of diagnosis is survived almost half of patients $-48.4 \%, 12$ and 24 months $16.1 \%$, and the period of up to 12 months $35.5 \%$. These relationships were statistically significant $(P<0.05)$ (Table 6).

The survival rate of 12 months in patients up to 70 years old is three times higher than in subjects above 70 years of age $(\mathrm{OR}=2.98)$, while the survival rate of 2 years in both age groups is similar ( $95 \%$ confidence interval for odds ratio is 1 , which means that the chances of survival are the same). However, taking into account the $\mathrm{N}$ type, the chance of survival of 24 months in a group of patients under 70 is four times higher than in older people $\left(\mathrm{OR}_{\mathrm{adj}}\right.$ $=4.78$ ), as illustrated in Table 7 .

\section{Surgical treatment and survival}

A statistically significant correlation was observed between surgical treatment and survival $(P<0.001)$. The survival rate of 12 months in surgical patients is almost three times higher than in non-surgically treated patients $(\mathrm{OR}=2.86)$; after $\mathrm{N}$ adjustment it increases to more than six times $\left(\mathrm{OR}_{\mathrm{adj}}=6.36\right)$. The chance of survival of 24 months in patients treated surgically is two and a half times higher than in non-surgically treated patients $(\mathrm{OR}=2.53)$. This data is presented in Tables 8 and 9 .

\section{Radiotherapy and survival}

A statistically significant relationship was observed between radiotherapy and survival $(P<0.001)$. The survival rate of 12-months in patients undergoing radiation therapy is almost seven times higher than in subjects treated in a different way $(\mathrm{OR}=6.80)$, and the survival rate of 24 months is four and a half times higher $(\mathrm{OR}=4.47)$. This data is presented in Tables 10 and 11.

Table 5 Number (percentage) of patients in groups differing in the extent of spread to the lymph nodes (N) and a I2-month survival or a 24 -month survival, the result of the test of independence, OR and its $95 \%$ confidence interval

\begin{tabular}{|c|c|c|c|c|}
\hline \multirow[t]{2}{*}{ Degree of spread to regional } & \multicolumn{2}{|c|}{ I 2-month survival } & \multirow[t]{2}{*}{$P$-value } & \multirow[t]{2}{*}{ OR $(95 \% \mathrm{Cl})$} \\
\hline & $\begin{array}{l}\text { Yes } \\
N=129\end{array}$ & $\begin{array}{l}\text { No } \\
N=104\end{array}$ & & \\
\hline $\begin{array}{l}\mathrm{N} 1 \text { or } \mathrm{N} 2 \\
\mathrm{~N} 3\end{array}$ & $\begin{array}{l}100(77.5 \%) \\
29(22.5 \%)\end{array}$ & $\begin{array}{l}33(31.7 \%) \\
71(68.3 \%)\end{array}$ & $<0.001$ & $\begin{array}{l}7.42 \text { (4.14-13.3) } \\
\text { I.00 (ref.) }\end{array}$ \\
\hline \multirow[t]{2}{*}{ Degree of spread to regional } & \multicolumn{2}{|c|}{ 24-month survival } & $P$-value & OR $(95 \% \mathrm{Cl})$ \\
\hline & $\begin{array}{l}\text { Yes } \\
N=83\end{array}$ & $\begin{array}{l}\text { No } \\
N=150\end{array}$ & & \\
\hline $\begin{array}{l}\text { N1 or N2 } \\
\text { N3 }\end{array}$ & $\begin{array}{l}66(79.5 \%) \\
17(20.5 \%)\end{array}$ & $\begin{array}{l}67(44.7 \%) \\
83(55.3 \%)\end{array}$ & $<0.001$ & $\begin{array}{l}4.8 \mathrm{I}(2.58-8.96) \\
\mathrm{I} .00 \text { (ref.) }\end{array}$ \\
\hline
\end{tabular}

Table 6 Number (percentage) of patients in groups differing in terms of age and survival, the result of the test of independence

\begin{tabular}{|c|c|c|c|c|c|}
\hline \multirow[t]{2}{*}{ Survival rate (months) } & \multicolumn{4}{|c|}{ Age (years) } & \multirow[t]{2}{*}{$P$-value } \\
\hline & $\begin{array}{l}<50 \\
N=31\end{array}$ & $\begin{array}{l}\text { From } 50 \text { to } 60 \\
N=82\end{array}$ & $\begin{array}{l}\text { From } 61 \text { to } 70 \\
N=92\end{array}$ & $\begin{array}{l}\text { More than } 70 \\
N=28\end{array}$ & \\
\hline$<12$ months & II (35.5\%) & 40 (48.8\%) & $34(37.0 \%)$ & 19 (67.9\%) & 0.036 \\
\hline From 12 to 24 months & $5(16.1 \%)$ & $16(19.5 \%)$ & $24(26.1 \%)$ & I (3.6\%) & \\
\hline More than 24 months & 15 (48.4\%) & 26 (31.7\%) & 34 (37.0\%) & $8(28.6 \%)$ & \\
\hline
\end{tabular}

Note: Bold value represents statistically significant. 
Table 7 Number (percentage) of patients in groups differing in terms of age and a 12-month survival or a 24-month survival, the result of the test of independence, $\mathrm{OR}$, adjusted by $\mathrm{N}$ odds ratio $\left(\mathrm{OR}_{\mathrm{adj}}\right)$ and their $\left.95 \% \mathrm{Cl}\right)$

\begin{tabular}{|c|c|c|c|c|c|}
\hline \multirow[t]{2}{*}{ Age (years) } & \multicolumn{2}{|c|}{ I2-month survival } & \multirow[t]{2}{*}{$P$-value } & \multirow[t]{2}{*}{ OR $(95 \% \mathrm{Cl})$} & \multirow[t]{2}{*}{ OR $_{\text {adj. }}(95 \% \mathrm{Cl})$} \\
\hline & $\begin{array}{l}\text { Yes } \\
N=129\end{array}$ & $\begin{array}{l}\text { No } \\
N=104\end{array}$ & & & \\
\hline $\begin{array}{l}\text { Up to } 70 \\
\text { Over } 70\end{array}$ & $\begin{array}{l}120(93.0 \%) \\
9(7.0 \%)\end{array}$ & $\begin{array}{l}85(81.7 \%) \\
19(18.3 \%)\end{array}$ & 0.015 & $\begin{array}{l}2.98(1.29-6.91) \\
1.00 \text { (ref.) }\end{array}$ & $\begin{array}{l}7.58(4.18-13.8) \\
1.00 \text { (ref.) }\end{array}$ \\
\hline \multirow[t]{2}{*}{ Age (years) } & \multicolumn{2}{|c|}{ 24-month survival } & $P$-value & OR $(95 \% \mathrm{Cl})$ & $\mathrm{OR}_{\mathrm{adj} .}(95 \% \mathrm{Cl})$ \\
\hline & $\begin{array}{l}\text { Yes } \\
N=83\end{array}$ & $\begin{array}{l}\text { No } \\
N=150\end{array}$ & & & \\
\hline $\begin{array}{l}\text { Up to } 70 \\
\text { Over } 70\end{array}$ & $\begin{array}{l}75(90.4 \%) \\
8(9.6 \%)\end{array}$ & $\begin{array}{l}130(86.7 \%) \\
20(13.3 \%)\end{array}$ & 0.535 & $\begin{array}{l}\mathrm{I} .44 \text { (0.6I-3.44) } \\
\mathrm{I} .00 \text { (ref.) }\end{array}$ & $\begin{array}{l}4.78 \text { (2.56-8.9I) } \\
\mathrm{I} .00 \text { (ref.) }\end{array}$ \\
\hline
\end{tabular}

Table 8 Number (percentage) of patients in groups differing in the surgical treatment and survival, the result of the test of independence

\begin{tabular}{|l|l|l|l|}
\hline \multirow{2}{*}{ Survival rate (months) } & \multicolumn{2}{|l|}{ Surgery } & \multirow{2}{*}{ P-value } \\
\cline { 2 - 3 } & $\begin{array}{l}\text { Yes } \\
\text { N=109 }\end{array}$ & $\begin{array}{l}\text { No } \\
\mathbf{N}=124\end{array}$ & \\
\hline$<12$ months & $34(31.2 \%)$ & $70(56.5 \%)$ & $<0.00$ I \\
From I2 to 24 months & $24(22.0 \%)$ & $22(17.7 \%)$ & \\
More than 24 months & $5 \mathrm{I}(46.8 \%)$ & $32(25.8 \%)$ & \\
\hline
\end{tabular}

Note: Bold value represents statistically significant.

\section{Chemotherapy and survival}

A statistically significant relationship was reported between chemotherapy and survival $(P<0.05)$. The survival rate of 12 months in patients undergoing chemotherapy is doubled as high as in subjects treated in a different way $(\mathrm{OR}=2.09)$ but the survival rate of 24 months is the same $(O R=1.72,95 \%$ confidence interval for the odds ratio contains one). However, taking into account the influence of tumor progression the survival rate increases to almost five $(\mathrm{OR}=4.86)$. This data is presented in Tables 12 and 13.

\section{Type of treatment and survival}

Table 14 presents the treatment methods used in CUP patients. The largest group of patients underwent surgical treatment and radiotherapy or radiochemotherapy, these groups achieved the best survival results.

\section{4-month survival}

Table 15 shows that the patients after surgical treatment $(\mathrm{OR}=4.37)$, followed by radiotherapy with chemotherapy $(\mathrm{OR}=4.29)$, had the best survival rate of 24 months. The patients undergoing only chemotherapy $(\mathrm{OR}=3.44)$ had the lowest survival rate of 24 months.

Table 9 Number (percentage) of patients in groups differing in the surgical treatment and a I2-month survival or a 24-month survival, the result of the test of independence, $\mathrm{OR}$, adjusted by $\mathrm{N}$ odds ratio $\left(\mathrm{OR}_{\mathrm{adj}}\right)$ and their $95 \% \mathrm{Cl}$

\begin{tabular}{|c|c|c|c|c|c|}
\hline \multirow[t]{2}{*}{ Surgery } & \multicolumn{2}{|c|}{ I2-month survival } & \multirow[t]{2}{*}{$P$-value } & \multirow[t]{2}{*}{ OR $(95 \% \mathrm{Cl})$} & \multirow[t]{2}{*}{ OR $_{\text {adj. }}(95 \% \mathrm{Cl})$} \\
\hline & $\begin{array}{l}\text { Yes } \\
N=129\end{array}$ & $\begin{array}{l}\text { No } \\
N=104\end{array}$ & & & \\
\hline $\begin{array}{l}\text { Yes } \\
\text { No }\end{array}$ & $\begin{array}{l}75(58.1 \%) \\
54(41.9 \%)\end{array}$ & $\begin{array}{l}34(32.7 \%) \\
70(67.3 \%)\end{array}$ & $<0.001$ & $\begin{array}{l}2.86(1.67-4.90) \\
1.00 \text { (ref.) }\end{array}$ & $\begin{array}{l}6.36(3.49-11.6) \\
1.00 \text { (ref.) }\end{array}$ \\
\hline \multirow[t]{2}{*}{ Surgery } & \multicolumn{2}{|c|}{ 24-month survival } & $P$-value & OR $(95 \% \mathrm{Cl})$ & $\mathrm{OR}_{\text {adj. }}(95 \% \mathrm{Cl})$ \\
\hline & $\begin{array}{l}\text { Yes } \\
N=83\end{array}$ & $\begin{array}{l}\text { No } \\
N=150\end{array}$ & & & \\
\hline $\begin{array}{l}\text { Yes } \\
\text { No }\end{array}$ & $\begin{array}{l}51(61.4 \%) \\
32(38.6 \%)\end{array}$ & $\begin{array}{l}58(38.7 \%) \\
92(61.3 \%)\end{array}$ & 0.001 & $\begin{array}{l}2.53 \text { (I.46-4.39) } \\
1.00 \text { (ref.) }\end{array}$ & $\begin{array}{l}4.13 \text { (2.18- 7.83) } \\
1.00 \text { (ref.) }\end{array}$ \\
\hline
\end{tabular}


Table 10 Number (percentage) of patients in groups differing in radiotherapy and survival, and the result of the test of independence

\begin{tabular}{|l|l|l|l|}
\hline \multirow{2}{*}{ Survival rate (months) } & \multicolumn{2}{|l|}{ Radiotherapy } & \multirow{2}{*}{-value } \\
\cline { 2 - 3 } & $\begin{array}{l}\text { Yes } \\
\text { N=166 }\end{array}$ & $\begin{array}{l}\text { No } \\
\text { N=67 }\end{array}$ & \\
\hline$<12$ months & $53(31.9 \%)$ & $51(76.1 \%)$ & $<0.001$ \\
From 12 to 24 months & $40(24.1 \%)$ & $6(9.0 \%)$ & \\
More than 24 months & $73(44.0 \%)$ & $10(14.9 \%)$ & \\
\hline
\end{tabular}

Note: Bold value represents statistically significant.

The comparison of CUP treatment methods revealed that the best survival rate was reported in patients treated surgically and using chemoradiotherapy, followed by those treated with chemoradiotherapy. The worst results were obtained in the patients treated with chemotherapy alone.

The results presented in Table 16 indicate a better prognosis for women and for the youngest patients. Status N1 and N2 also gives better survival compared to $\mathrm{N} 3$ patients. The worst prognosis was reported in N4 and N5 patients. Tonsillectomy used as a diagnostic method statistically significantly improves the prognosis of CUP patients. The best prognosis is reported in patients undergoing surgical treatment and radiotherapy, these results are statistically significant. The patients in a better general state according to ECOG $0-1$ achieved better results of treatment.

\section{Discussion}

CUP was first described by Comess et al in $1957 .^{12}$ According to the principle of Martin and Rumieu, the asymmetrical enlargement of one or more lymph nodes in the neck of an adult is almost always a symptom of a malignant tumor and it is usually a metastasis from the head and neck region.

According to the guidelines of the European Society for Medical Oncology, the diagnosis of CUP requires an accurate medical history. A physical examination, laboratory tests of urine, blood, blood in the stool, CT of the chest, abdomen and pelvis, PET and panendoscopy are also necessary.

According to many sources, CT and MRI are characterized by low, because only $10 \%$ detection of the primary site. According to other sources, the detection ranges between $8 \%$ and $23 \% .{ }^{10}$ According to various sources as PET is more useful test it allows for detection of $10-35 \%$ of primary sites. ${ }^{2,13,14}$ PET has a high sensitivity of around $97 \%$ and low specificity of $68 \% .{ }^{15}$ According to Guardiola et al, PET is an alternative to panendoscopy, however, we believe that it is a complementary examination. ${ }^{16}$ It should be noted that PET may give false results, for instance, an inflammatory process in the palatine tonsils may incorrectly indicate the presence of cancer. False results are also reported when the uptake is considered physiological. ${ }^{17} \mathrm{~A}$ detection of the primary site is significantly enhanced by the examinations of neoplastic markers in combination with imaging diagnostics, especially in breast, prostate, liver and stomach cancer. To date, neoplastic markers of head and neck cancers have not been identified. All women with CUP should have mammography.

Panendoscopy has been used for a long time in the diagnosis of CUP but its usefulness is discussed by many authors. ${ }^{16}$ During panendoscopy, blind biopsy of the suspected mucous membrane within the nasopharynx, oropnarynx, hypopharynx and bilateral

Table I I Number (percentage) of patients in groups differing in radiotherapy and a I2-month survival or a 24-month survival, the result of the test of independence, $\mathrm{OR}$, adjusted by $\mathrm{N}$ odds ratio $\left(\mathrm{OR}_{\mathrm{adj}}\right)$ and their $95 \% \mathrm{Cl}$

\begin{tabular}{|c|c|c|c|c|c|}
\hline \multirow[t]{2}{*}{ Radiotherapy } & \multicolumn{2}{|c|}{ I 2-month survival } & \multirow[t]{2}{*}{$P$-value } & \multirow[t]{2}{*}{ OR $(95 \% \mathrm{Cl})$} & \multirow[t]{2}{*}{ OR $_{\text {adj. }}(95 \% \mathrm{Cl})$} \\
\hline & $\begin{array}{l}\text { Yes } \\
N=129\end{array}$ & $\begin{array}{l}\text { No } \\
N=104\end{array}$ & & & \\
\hline $\begin{array}{l}\text { Yes } \\
\text { No }\end{array}$ & $\begin{array}{l}113(87.6 \%) \\
16(12.4 \%)\end{array}$ & $\begin{array}{l}53(51.0 \%) \\
51(49.0 \%)\end{array}$ & $<0.001$ & $\begin{array}{l}6.79(3.55-13.0) \\
1.00 \text { (ref.) }\end{array}$ & $\begin{array}{l}6.37(3.3 \mathrm{I}-2.3) \\
\mathrm{I} .00 \text { (ref.) }\end{array}$ \\
\hline \multirow[t]{2}{*}{ Radiotherapy } & \multicolumn{2}{|c|}{ 24-month survival } & $P$-value & OR $(95 \% \mathrm{Cl})$ & $\mathrm{OR}_{\mathrm{adj} .}(95 \% \mathrm{Cl})$ \\
\hline & $\begin{array}{l}\text { Yes } \\
N=83\end{array}$ & $\begin{array}{l}\text { No } \\
N=150\end{array}$ & & & \\
\hline Yes & $73(88.0 \%)$ & $93(62.0 \%)$ & 0.001 & $4.47(2.14-9.36)$ & $3.27(1.68-6.37)$ \\
\hline No & 10 (I2.0\%) & 57 (38.0\%) & & I.00 (ref.) & I.00 (ref.) \\
\hline
\end{tabular}


Table 12 Number (percentage) of patients in groups differing in chemotherapy and survival, the result of the test of independence

\begin{tabular}{|l|l|l|l|}
\hline \multirow{2}{*}{ Survival rate (months) } & \multicolumn{2}{|l|}{ Chemotherapy } & \multirow{2}{*}{ P-value } \\
\cline { 2 - 3 } & $\begin{array}{l}\text { Yes } \\
\text { N=135 }\end{array}$ & $\begin{array}{l}\text { No } \\
\text { N=98 }\end{array}$ & \\
\hline$<12$ months & $50(37.0 \%)$ & $54(55.1 \%)$ & \multirow{0}{0.023}{} \\
From 12 to 24 months & $30(22.2 \%)$ & $16(16.3 \%)$ & \\
More than 24 months & $55(40.8 \%)$ & $28(28.6 \%)$ & \\
\hline
\end{tabular}

Note: Bold value represents statistically significant.

tonsillectomy should be performed. ${ }^{18}$ Taking specimens or performing tonsillectomy has a diagnostic importance. Our work also confirmed a very important relationship between detection of the primary site, biopsy and tonsillectomy. According to the literature, unilateral tonsillectomy of the enlarged nodes detects $18-44 \%$ of primary sites, ${ }^{19,20}$ whereas contralateral tonsillectomy detects $10-23 \%$ of primary sites. ${ }^{21}$ Tonsilletomy should always be carried out when the primary site is undetectable in imaging studies and the results of biopsy are negative. When the result of palatal tonsilectomy is also negative, the removal of the lingual tonsil should be considered.

In most cases of CUP, the level of malignancy is high, and the degree of tumor differentiation is low G3 or there is a lack of differentiation G4. Because of the difficulties in the detection of primary sites in imaging procedures, such as CT, MRI and PET, it is very important to determine the histopathological type of the tumor. The histopathological evaluation of CUP is troublesome, requires staining with vimentin, cluster of differentiation CD 45 , HM B-45 and pancytokeratin. Histopathological diagnostics also use CK7 and CK20 antibodies. A histopathological diagnosis makes it possible to suspect the location of the primary site, which allows for the implementation of oncological treatment. Organ-specific

Table 13 Number (percentage) of patients in groups differing in chemotherapy and a 12-month survival or a 24-month survival, the result of the test of independence, $\mathrm{OR}$, adjusted by $\mathrm{N}$ odds ratio $\left(\mathrm{OR}_{\mathrm{adj}}\right)$ and their $95 \% \mathrm{Cl}$

\begin{tabular}{|c|c|c|c|c|c|}
\hline \multirow[t]{2}{*}{ Chemotherapy } & \multicolumn{2}{|c|}{ I 2-month survival } & \multirow[t]{2}{*}{$P$-value } & \multirow[t]{2}{*}{ OR $(95 \% \mathrm{Cl})$} & \multirow[t]{2}{*}{ OR $_{\text {adj. }}(95 \% \mathrm{Cl})$} \\
\hline & $\begin{array}{l}\text { Yes } \\
N=129\end{array}$ & $\begin{array}{l}\text { No } \\
N=104\end{array}$ & & & \\
\hline $\begin{array}{l}\text { Yes } \\
\text { No }\end{array}$ & $\begin{array}{l}85 \text { (65.9\%) } \\
44(34.1 \%)\end{array}$ & $\begin{array}{l}50(48.1 \%) \\
54(51.9 \%)\end{array}$ & 0.006 & $\begin{array}{l}2.09 \text { (I.23-3.54) } \\
1.00 \text { (ref.) }\end{array}$ & $\begin{array}{l}8.05(4.38-14.8) \\
1.00 \text { (ref.) }\end{array}$ \\
\hline \multirow[t]{2}{*}{ Chemotherapy } & \multicolumn{2}{|c|}{ 24-month survival } & $P$-value & OR $(95 \% \mathrm{Cl})$ & $\mathrm{OR}_{\text {adj. }}(95 \% \mathrm{Cl})$ \\
\hline & $\begin{array}{l}\text { Yes } \\
N=83\end{array}$ & $\begin{array}{l}\text { No } \\
N=150\end{array}$ & & & \\
\hline $\begin{array}{l}\text { Yes } \\
\text { No }\end{array}$ & $\begin{array}{l}55(66.3 \%) \\
28(33.7 \%)\end{array}$ & $\begin{array}{l}80(53.3 \%) \\
70(46.7 \%)\end{array}$ & 0.056 & $\begin{array}{l}1.72 \text { (0.99-3.00) } \\
1.00 \text { (ref.) }\end{array}$ & $\begin{array}{l}4.86 \text { (2.55-9.25) } \\
1.00 \text { (ref.) }\end{array}$ \\
\hline
\end{tabular}

Table 14 Number (percentage) of patients in groups differing in the type of treatment and survival, the result of the test of independence

\begin{tabular}{|c|c|c|c|c|}
\hline & \multicolumn{3}{|c|}{ Survival rate (months) } & \multirow[t]{2}{*}{$P$-value } \\
\hline & $\begin{array}{l}<12 \\
N=93\end{array}$ & $\begin{array}{l}12-24 \\
N=46\end{array}$ & $\begin{array}{l}>24 \\
N=82\end{array}$ & \\
\hline Surgery only $(n=18)$ & $9(50.0 \%)$ & $4(22.2 \%)$ & $5(27.8 \%)$ & 0.680 \\
\hline Radiotherapy only $(n=30)$ & $8(26.7 \%)$ & $6(20.0 \%)$ & $16(53.3 \%)$ & 0.109 \\
\hline Chemotherapy only $(n=22)$ & 20 (91.0\%) & I (4.5\%) & I (4.5\%) & $<0.001$ \\
\hline Surg. \& Rad. $(n=30)$ & $8(26.7 \%)$ & $6(20.0 \%)$ & $16(53.3 \%)$ & 0.063 \\
\hline Surg. \& Chem. $(n=16)$ & $12(75.0 \%)$ & $\mathrm{I}(6.2 \%)$ & $3(18.8 \%)$ & 0.039 \\
\hline Rad. \& Chem. $(n=52)$ & $13(25.0 \%)$ & $15(28.8 \%)$ & $24(46.2 \%)$ & 0.005 \\
\hline Surg. \& Rad. \& Chem. $(n=44)$ & $4(9.1 \%)$ & $13(29.6 \%)$ & 27 (6I.4\%) & $<0.001$ \\
\hline
\end{tabular}

Note: Bold value represents statistically significant. 
Table 15 Number (percentage) of patients in groups differing in the type of treatment and a 24-month survival, the result of the test of independence, $\mathrm{OR}$, adjusted by $\mathrm{N}$ odds ratio $\left(\mathrm{OR}_{\mathrm{adj}}\right)$ and their $95 \% \mathrm{Cl}$

\begin{tabular}{|c|c|c|c|c|c|}
\hline & \multicolumn{2}{|c|}{ 24-moths survival } & \multirow[t]{2}{*}{$P$-value } & \multirow[t]{2}{*}{ OR (95\% Cl) } & \multirow[t]{2}{*}{ OR $_{\text {adj. }}(95 \% \mathrm{Cl})$} \\
\hline & $\begin{array}{l}\text { Yes } \\
\mathrm{N}=82\end{array}$ & $\begin{array}{l}\text { No } \\
N=139\end{array}$ & & & \\
\hline Surgery only & $5(6.1 \%)$ & 13 (9.4\%) & 0.393 & $0.63(0.22-1.83)$ & $4.37(2.31-8.27)$ \\
\hline Radiotherapy only & $6(7.3 \%)$ & $33(23.7 \%)$ & 0.002 & $0.25(0.10-0.64)$ & $4.01(2.11-7.64)$ \\
\hline Chemotherapy only & $\mathrm{I}(\mathrm{I} .2 \%)$ & 21 (15.1\%) & $<0.001$ & $0.07(0.01-0.57)$ & $3.44(1.80-6.47)$ \\
\hline Surg. \& Rad. & 16 (19.3\%) & 14 (9.3\%) & 0.030 & $2.32(1.07-5.03)$ & $4.04(2.14-7.6 I)$ \\
\hline Surg. \& Chem. & $3(3.6 \%)$ & $13(8.7 \%)$ & 0.182 & $0.40(0.11-1.43)$ & $4.09(2.15-7.68)$ \\
\hline Rad. \& Chem. & 24 (28.9\%) & $28(18.7 \%)$ & 0.072 & $1.77(0.95-3.32)$ & $4.29(2.13-8.66)$ \\
\hline Surg. \& Rad. \& Chem. & 27 (32.5\%) & 17 (11.3\%) & $<0.001$ & 3.77 (1.91-7.46) & $3.62(1.79-7.32)$ \\
\hline
\end{tabular}

Abbreviations: surg., surgery; rad., radiotherapy; chem., chemotherapy.

antibodies can also be used to exclude or confirm the primary site (PSA, GCDFP15, CDX2, WT1, CA125, TTf). Genetic tests are also very helpful in diagnosis. ${ }^{22,23}$ In our opinion, the histopathological diagnosis is the most important determinant of oncological treatment and prognosis. According to some authors, histopathological examinations and genetic tests allow for the detection of $80 \%$ of primary sites. $^{23}$

According to the literature, SCC is the most common histopathological type of CUP (65-76\%); our study also detected SCC in the majority of patients.

CUP is more frequent among men, with the average age of onset 55-65 which is consistent with our results.

According to Enyinnaya et al, N1 type was found in $1 \%$, N2 in $69.5 \%$ and N3 in $32 \% .^{24}$ Similar results were obtained in our study. This proves the detection of nodal metastases at higher stages of progression. Bilateral metastases were found in $8.7 \%$ and unilateral in $92.3 \%$, more often on the left side. ${ }^{25}$ According to Yan Wang et al, N1 was found in $50 \%, \mathrm{~N} 2$ in $40 \%$ and $\mathrm{N} 3$ in $9.2 \%$ of the patients. ${ }^{1}$

According to Yu-Hsuan-Hung et al, metastatic lymph nodes are usually reported in the neck regions II, III, IV; similar results were obtained in our study. ${ }^{25}$ According to Nabili et al, regions II and III are also the most frequently affected areas of the neck. ${ }^{2}$

According to the literature, the frequency of detecting primary sites is $0-21 \%{ }^{26}$

Neck dissection or biopsy cutting out the enlarged lymph nodes is the gold standard and the first stage of oncological treatment. ${ }^{22}$ As confirmed by our study, surgical treatment combined with complementary therapy, like radiochemotherapy or radiotherapy, gives the best outcomes. Surgical treatment also uses transoral laser surgery (TOLS) and transoral robotic surgery (TORS) which, according to some authors, give better results than the classic surgery. TORS and TOLS are safer, with only $5 \%$ of postoperative bleeds. Molecular target therapy, as an experimental treatment, is also an alternative as a supplement to oncological treatment. According to Yu-Hsuan-Hung et al, neck dissection with radiotherapy or radiochemotherapy was performed in $58 \%$ of the patients, $7.2 \%$ had neck dissection, $21.7 \%$ radiochemotherapy and $13 \%$ were treated with radiotherapy only. ${ }^{25}$ In our study, $76 \%$ of the subjects underwent neck dissection. The majority of the patients received surgical treatment supplemented with radiotherapy or radiochemotherapy.

In the study of Yu-Hsuan-Hung et al, local recurrence was found in $42 \%$ of patients, with the mean recurrence time 10 months. $^{25}$ According to Basel et al, 78\% of the patients had recurrence and $80 \%$ had distant metastases. $^{27}$ According to different authors, local recurrence is reported in $9-59 \%$ and distant metastases in $3.5 \%$ to $38 \%$. The risk of recurrence depends on the severity of lesions in the lymph nodes, histopathological type, type of treatment, the presence of positive margins after surgery, and it is higher among the male sex.

According to the literature, HPV-dependent CUP is reported in $22-74 \%$ of patients, with the majority of HPV infections detected in highly developed countries; alcohol and smoking are risk factors in developing or less developed countries. ${ }^{27}$

A 2-year survival in patients from the study of Christiansen et al was $60 \%{ }^{26}$ The best results of treatment were noted in patients with the low stage N1 and 
Table 16 The assessment of patients' survival depending on sex, age, stage of disease, diagnostic procedures and treatment

\begin{tabular}{|c|c|c|c|c|}
\hline \multirow[t]{2}{*}{ Variable } & \multicolumn{3}{|c|}{ Survival rate (months) } & \multirow[t]{2}{*}{$P$-value } \\
\hline & $\begin{array}{l}<12 \\
N=104\end{array}$ & $\begin{array}{l}I 2-24 \\
N=46\end{array}$ & $\begin{array}{l}>24 \\
N=83\end{array}$ & \\
\hline $\begin{array}{l}\text { Gender: } \\
\text { Female } \\
\text { Male }\end{array}$ & $\begin{array}{l}17(16.3 \%) \\
87(83.7 \%)\end{array}$ & $\begin{array}{l}12(26.1 \%) \\
34(73.9 \%)\end{array}$ & $\begin{array}{l}27(32.5 \%) \\
56(67.5 \%)\end{array}$ & 0.034 \\
\hline $\begin{array}{l}\text { Age (years): } \\
\qquad 50 \\
\begin{array}{l}<0-60 \\
60-70 \\
>70\end{array}\end{array}$ & $\begin{array}{l}11(10.6 \%) \\
40(38.5 \%) \\
34(32.7 \%) \\
19(18.3 \%)\end{array}$ & $\begin{array}{l}5(10.9 \%) \\
16(34.8 \%) \\
24(52.2 \%) \\
I(2.1 \%)\end{array}$ & $\begin{array}{l}15(18.1 \%) \\
26(31.3 \%) \\
34(41.0 \%) \\
8(9.6 \%)\end{array}$ & 0.036 \\
\hline $\begin{array}{l}\text { Degree of spread to regional } \\
\text { NI } \\
\text { N2 } \\
\text { N3 }\end{array}$ & $\begin{array}{l}10(9.6 \%) \\
23(22.1 \%) \\
71(68.3 \%)\end{array}$ & $\begin{array}{l}9(19.6 \%) \\
25(54.4 \%) \\
12(26.1 \%)\end{array}$ & $\begin{array}{l}14(16.9 \%) \\
52(62.6 \%) \\
17(20.5 \%)\end{array}$ & $<0.001$ \\
\hline $\begin{array}{l}\text { Panendoscopy revealed primary tumor } \\
\text { Yes } \\
\text { No }\end{array}$ & $\begin{array}{l}n=23 \\
7(30.4 \%) \\
16(69.6 \%)\end{array}$ & $\begin{array}{l}n=31 \\
12(38.7 \%) \\
19(61.3 \%)\end{array}$ & $\begin{array}{l}n=5 \mid \\
17(33.3 \%) \\
34(66.7 \%)\end{array}$ & 0.802 \\
\hline $\begin{array}{l}\text { PET - revealed primary tumor } \\
\text { Yes } \\
\text { No }\end{array}$ & $\begin{array}{l}n=21 \\
8(38.1 \%) \\
13(61.9 \%)\end{array}$ & $\begin{array}{l}n=16 \\
8(50.0 \%) \\
8(50.0 \%)\end{array}$ & $\begin{array}{l}n=33 \\
15(45.5 \%) \\
18(54.5 \%)\end{array}$ & 0.757 \\
\hline $\begin{array}{l}\text { Cervical lymph node groups: } \\
\text { I } \\
\text { II } \\
\text { III } \\
\text { IV } \\
\text { V } \\
\text { VI }\end{array}$ & $\begin{array}{l}7(6.7 \%) \\
91(87.5 \%) \\
70(67.3 \%) \\
41(39.4 \%) \\
23(22.1 \%) \\
2(1.9 \%)\end{array}$ & $\begin{array}{l}\text { I }(2.2 \%) \\
39(84.8 \%) \\
28(60.9 \%) \\
7(15.2 \%) \\
3(6.5 \%) \\
0(0.0 \%)\end{array}$ & $\begin{array}{l}\text { I }(1.2 \%) \\
75(90.4 \%) \\
46(55.4 \%) \\
\text { II (I3.3\%) } \\
5(6.0 \%) \\
0(0.0 \%)\end{array}$ & $\begin{array}{l}0.120 \\
0.634 \\
0.249 \\
<0.001 \\
0.002 \\
0.286\end{array}$ \\
\hline Tonsillectomy & $4(3.8 \%)$ & 14 (30.4\%) & $19(22.9 \%)$ & $<0.001$ \\
\hline $\begin{array}{l}\text { Pathologic type: } \\
\qquad \begin{array}{l}\text { I - squamous cell carcinoma } \\
2 \text { - adenocarcinoma } \\
3 \text { - melanoma } \\
4 \text { - lymphoma } \\
5 \text { - other }\end{array}\end{array}$ & $\begin{array}{l}90(86.5 \%) \\
2(1.9 \%) \\
1(1.0 \%) \\
0(0.0 \%) \\
I I(10.6 \%)\end{array}$ & $\begin{array}{l}38(82.6 \%) \\
3(6.5 \%) \\
4(8.7 \%) \\
\text { I }(2.2 \%) \\
0(0.0 \%)\end{array}$ & $\begin{array}{l}74(89.2 \%) \\
3(3.6 \%) \\
3(3.6 \%) \\
0(0.0) \\
3(3.6 \%)\end{array}$ & 0.090 \\
\hline Surgery & $34(32.7 \%)$ & $24(52.2 \%)$ & $5 \mathrm{I}(6 \mathrm{I} .4 \%)$ & $<0.001$ \\
\hline Radiotherapy & $53(51.0 \%)$ & $40(87.0 \%)$ & $73(88.0 \%)$ & $<0.001$ \\
\hline Chemotherapy & $50(48.1 \%)$ & $30(65.2 \%)$ & $55(66.3 \%)$ & 0.023 \\
\hline $\begin{array}{l}\text { ECOG performance status: } \\
\qquad 0 \\
1 \\
2 \\
3 \\
4\end{array}$ & $\begin{array}{l}19(18.3 \%) \\
55(52.9 \%) \\
23(22.1 \%) \\
6(5.8 \%) \\
1(1.0 \%)\end{array}$ & $\begin{array}{l}25(54.3 \%) \\
20(43.5 \%) \\
\text { I (2.2\%) } \\
0(0.0 \%) \\
0(0.0 \%)\end{array}$ & $\begin{array}{l}59(71.1 \%) \\
21(25.3 \%) \\
2(2.4 \%) \\
1(1.2 \%) \\
0(0.0 \%)\end{array}$ & $<0.001$ \\
\hline
\end{tabular}


Table 16 (Continued).

\begin{tabular}{|c|c|c|c|c|}
\hline \multirow[t]{2}{*}{ Variable } & \multicolumn{3}{|c|}{ Survival rate (months) } & \multirow[t]{2}{*}{$P$-value } \\
\hline & $\begin{array}{l}<12 \\
N=104\end{array}$ & $\begin{array}{l}12-24 \\
N=46\end{array}$ & $\begin{array}{l}>24 \\
N=83\end{array}$ & \\
\hline Treatment: & & & & $<0.001$ \\
\hline Radical & $23(22.1 \%)$ & 35 (76.1\%) & 77 (92.8\%) & \\
\hline Palliative & 81 (77.9\%) & II (23.9\%) & $6(7.2 \%)$ & \\
\hline
\end{tabular}

Note: Bold values represent statistically significant.

Abbreviations: ECOG, Eastern Cooperative Oncology Group.

N2 and treated with ND plus radiotherapy or radiochemotherapy $-67 \%$ of 2 -year survivals, and with radiochemotherapy only $-66 \%$ of 2 -year survivals. Twentytwo percent of the patients from the study treated with radiotherapy showed only a 2-year survival. However, according to Jensen et al, a 2-year survival was reported in $45 \%$ and a 5 -year survival in $30 \%{ }^{28}$ In various works, a 5-year survival was noted in $20-74 \%$. Such divergent results are most likely due to different selection of groups for research, the size of groups and the exclusion of palliative patients from some studies.

According to some authors, surgery is the best method of treatment while others recommend radiochemotherapy. According to Guntinas-Lichius O. et $\mathrm{al}^{6}$, chemotherapy as an adjuvant to radiotherapy has no effect; however, the European Organization for Research and Treatment of Cancer recommends radiochemotherapy as an adjuvant method for surgery, with a reduction of the risk of progression by $25 \%$ and mortality by $30 \%$ in the first 5 years.

Diagnosis and treatment of CUP is still unsatisfactory, with $50-70 \%$ of the sites detected in postmortem examinations. ${ }^{29}$

\section{Limitation of the study}

The study has a retrospective character and was not randomized. The CUP patients were divided into groups based on the progression of lesions; as it was impossible to obtain similar number of subjects in the groups, this condition should be met in the next study in order to compare the groups. Not each patient had a PET because of financial issues. The impact of lifestyle on the development of CUP was not evaluated. The subjects were treated for several years over which the diagnostic and therapeutic standards slightly changed. Therefore, further research is required to ultimately determine the diagnostic and treatment protocol for CUP patients.

\section{Conclusions}

Tonsillectomy is required in CUP patients with the negative results of biopsy and imaging tests. It gives a possibility of detecting the primary site and improves the results of treatment and survival of CUP patients.

Combination therapy, including surgical treatment and chemoradiotherapy, gives the best therapeutic results in CUP patients.

The general condition and younger age have an impact on prognosis and survival.

\section{Ethics and consent}

All procedures performed in studies involving human participants were in accordance with the ethical standards of the institutional and national research committee and with the 1964 Helsinki declaration and its later amendments or comparable ethical standards. No patient personal data was used in this study. The study was accepted by ethics committee in Wroclaw Medical University. Informed consent was not required from all individual participants included in the study. It was a retrospective study. This study was not funded.

\section{Disclosure}

The authors report no conflicts of interest in this work.

\section{References}

1. Wang Y, He -S-S, Bao Y, et al. Cervical lymph node carcinoma metastasis from unknown primary site: a retrospective analysis of 154 patients. Cancer Med. 2018;7(5):1852-1859.

2. Nabili V, Zaia B, Blackwell KE, Head CS, Grabski K, Sercarz JA. Position emission tomography: poor sensitivity for occult tonsillar cancer. Am J Otolaryngol Head Neck Med Surg. 2007;28:153-157.

3. Bree R. The real additional value of FDG-PET in detecting the occult primary tumour in patient with cervical lymph node metastases of unknown primary tumour. Eur Arch Otorhinolaryngol. 2010;267:1653-1655. doi:10.1007/s00405-010-1372-2

4. Chen YJ, Chang JT, Liao CT, et al. Head and neck cancer in the betel quid chewing area: recent advances in molecular carcinogenesis. Cancer Sci. 2008;99(8):1507-1514. doi:10.1111/j.1349-7006.2008. 00863.x 
5. Kobayashi K, Saito Y, Omura G, et al. Clinical features of human papilloma virus-related head and neck squamous cell carcinoma of an unknown primary site. ORL $J$ Otorhinolaryngol Relat Spec. 2014;76:137-146. doi:10.1159/000369143

6. Guntinas-Lichius O, Peter Klussmann J, Dinh S, et al. Diagnostic work- up and outcome of cervical metastases from an unknown primary. Acta Otolaryngol. 2006;126:536-544. doi:10.1080/ 00016480500417304

7. Koivunen P, Bäck L, Laranne J, Irjala H. Unknown primary: diagnosticissues in the biological endoscopy and positron emission tomography scan era. Curr Opin Otolaryngol Head Neck Surg. 2015;23:121-126. doi:10.1097/MOO.0000000000000145

8. Yasui T, Morii E, Yamamoto Y, et al. Human papillomavirus and cystic node metastasis in oropharyngeal cancer and cancer of unknown primary origin. PLoS One. 2014;9:e95364. doi:10.1371/ journal.pone. 0095364

9. Nagel TH, Hinni ML, Hayden RE, Lott DG. Transoral laser microsurgery for the unknown primary: role for lingual tonsillectomy. Head Neck. 2014;36:942-946. doi:10.1002/hed.23372

10. Waltonen JD, Ozer E, Hall NC, Schuller DE, Agrawal A. Metastatic carcinoma of the neck of unknown primary origin: evolution and efficacy of the modern workup. Arch Otolaryngol Head Neck Surg. 2009;135:1024-1029. doi:10.1001/archoto.2009.145

11. Funk GF. A head and neck surgeon's perspective on best practices for the use of PET/CT scans for the diagnosis and treatment of head and neck cancers. Arch Otolaryngol Head Neck Surg. 2012;138:748-752. doi:10.1001/2013.jamaoto.115

12. Comess MS, Beahrs OH, Dockerty MB. Cervical metastasis from occult carcinoma. Surg Gynecol Obstet. 1957;104:607-617.

13. Hayashi T, Muto M, Hayashi R, Minashi K, Yano T, Iiwsp KS. Usefulness of narrow-band imaging for detection the primary tumor site in patients with primary unknown cervical lymph node metastasis. Jpn J Clin Oncol. 2010;40(6):537-541. doi:10.1093/jjco/hyp197

14. Rades D, Kühnel G, Wildfang I, Börner AR, Schmoll HJ, Knapp W. Localised disease in can- cer of unknown primary (CUP): the value of positron emission tomography (PET) for individual therapeutic management. Ann Oncol. 2001;12:1605-1609. doi:10.1023/ A:1013107732572

15. Zhu L, Wang N. 18F-fluorodeoxyglucose positron emission tomography-computed tomography as a diagnostic tool in patients with cervical nodal metastases of unknown primary site: a meta-analysis. Surg Oncol. 2013;22:19. doi:10.1016/j.suronc.2013.06.002

16. Hermans R. Imaging in cervical nodal metastases of unknown primary. Cancer Imaging. 2011;11:9-14. doi:10.1102/1470-7330.2011.0002

17. Guardiola E, Chaigneau L, Villanueva C, Pivot X. Is there still a role for triple endoscopy as part of staging for head and neck cancer? Curr Opin Otolaryngol Head Neck Surg. 2006;14:85-88. doi:10.1097/01.moo.0000193177.62074.fd
18. Cianchetti M, Mancuso AA, Amdur RJ et al. Diagnostic evaluation of squamous cell carcinoma metastatic to cervical lymph nodes from an unknown head and neck primary site. Laryngoscope. 2009;119:2348-2354. doi:10.1002/lary.20638

19. Lapeyre M, Malissard L, Peiffert D et al. Cervical lymph node metastasis from an unknown primary: is a tonsillectomy necessary? Int J Radiat Oncol Biol Phys. 1997;39:291-296. doi:10.1016/S03603016(97)00321-0

20. Kothari P, Randhawa PS, Farrell R. Role of tonsillectomy in the search for a squamous cell carcinoma from an unknown primary in the head and neck. Br J Oral Maxillofac Surg. 2008;46:283-287. doi:10.1016/j.bjoms.2007.11.017

21. Fu TS, Foreman A, Goldstein DP, de Almeida JR, et al. The role of transoral robotic surgery, transoral laser microsurgery, and lingual tonsillectomy in the identification of head and neck squamous cell carcinoma of unknown primary origin: a systematic review. J Otolaryngol Head Neck Surg. 2016;45:28. doi:10.1186/s40463016-0142-6

22. Natoli C, Ramazzotti V, Nappi O, et al. Unknown primary tumors: review. Biochim Biophys Acta. 2011;1816:13-24. doi:10.1016/j. bbcan.2011.02.002

23. Pentheroudakis G, Golfinopoulos V, Pavlidis N. Switching benchmarks in cancer of unknown primary: from autopsy to microarray. Eur J Cancer. 2007;43:2026-4036. doi:10.1016/j. ejca.2007.06.023

24. Ofo E, Spiers H, Kim D, Duvvuri U. Transoral robotic surgery and the unknown primary. Orl. 2018;80:148-155. doi:10.1159/ 000490596

25. Hung Y-H, Liu S-A, Wang -C-C, Wang C-P, Jiang R-S, Wu S-H. Treatment outcomesof unknown primary squamous cell carcinoma of the head and neck. PLoS One. 2018;13(10):e0205365. doi:10.1371/ journal.pone. 0205365

26. Christiansen H, Hermann RM, Martin A, Nitsche M, Schmidberger H, Pradier O. Neck lymph node metastases from an unknown primary tumor retrospective study and review of literature. Strahlenther Onkol. 2005;181:355-362. doi:10.1007/s00066-005-1338-2

27. Al Kadah B, Papaspyrou G, Linxweiler M, et al. Cancer of unknown primary (CUP) of the head and neck: retrospective analysis of 81 patients. Eur Arch Otorhinolaryngol. 2017;274:2557-2566. doi:10.1007/s00405-017-4525-8

28. Jensen DH, Hedback N, Specht L, et al. Human papillomavirus in head and neck squamous cellcarcinoma of unknown primary is a common event and a strong predictorof survival. PLoS One. 2014;9(11):e110456. doi:10.1371/journal.pone.0110456

29. Neben K, Hübner G, Folprecht G, Jäger D, Krämer A. Metastases in the absence of primary tumor. advances in the diagnosis and treatment of CUP syndrome. Dtsch Arztebl Int. 2008;105(43):733-740. doi:10.3238/arztebl.2008.0733

\section{Publish your work in this journal}

Cancer Management and Research is an international, peer-reviewed open access journal focusing on cancer research and the optimal use of preventative and integrated treatment interventions to achieve improved outcomes, enhanced survival and quality of life for the cancer patient.
The manuscript management system is completely online and includes a very quick and fair peer-review system, which is all easy to use Visit http://www.dovepress.com/testimonials.php to read real quotes from published authors. 